both parts of the Mathematical Tripos, being bracketed equal to the seventeenth wrangler in Part I. She also had charge of the telescope at Newnham. After leaving Cambridge she became head of the Physics Department in the London (Royal Free Hospital) School of Medicine for Women, a post which she resigned in 1915 to take up war work. She joined the Scottish Women's Hospitals and served first in the Tent Hospital at Troyes where she put up and ran the X-ray Department, and afterwards in Serbia, where the unit was ordered by the French authorities. Later she became lecturer in physics at the King's College for Household and Social Science.

Edith Stoney travelled considerably, and a visit to Australia convinced her of the need for visits from Great Britain to the Dominions. She supported these views practically and generously by her gifts to the British Federation of University Women of research studentships in science to enable younger women graduates of the universities of Great Britain and Ireland, who were also members of the Federation, to go to these countries. She was so pleased with the success of her first scholars in Australia and New Zealand that this year she gave a sixth studentship, this time to be held in South Africa, to which the award was made at a meeting attended by Miss Stoney only a week before she died. The subjects of the studentships awarded included biochemistry, zoology (insect parasites) and botany. It is learned that in her will she has left money to the Federation for the continuance of these Johnstone and Florence Stoney Studentships. Her association with the Federation has been a great stimulus and pleasure to her fellow-members, who will be deeply sensible of the loss they have sustained in her death.

\section{Prof. Rudolf Vondráček}

By the death of Prof. R. Vondráček at Brno on June 12, Czechoslovakia has lost a distinguished chemist and technologist. Vondráček began his career as a research worker in pure and applied chemistry whilst completing his studies under Prof. Votoček at Prague, with whom he investigated the separation of certain reducing sugars by hydrazine. Altogether he contributed about fifty original papers to Central European periodicals and he was the author of four text-books.

After a period spent in the laboratories of industrial concerns and during which his researches related mainly to analytical methods, Vondráček spent some time before and during the Great War as an examiner for the Austrian Patent Office in Vienna. In December 1918 he returned to Czechoslovakia to take up the appointment as professor of chemistry at the Brmo Polytechnic, a post he held until his death. During this time he was twice dean (1920-21 and 1930-31) and he filled the office of rector during the session 1935-36.

His most important researches are connected with a study of the corrosion of metals and with the chemistry and physics of fuel technology. He made careful investigations into the calorific value of various fuels and directed attention to certain anomalies in fuel analysis such as the variation in the estimated water content, an apparently greater loss being recorded at $100^{\circ} \mathrm{C}$. than at $105^{\circ} \mathrm{C}$. He noticed, too, a 'timelag' in the absorption of moisture by coal.

Prof. Vondráček was an authority on the destructive distillation of fuels at low temperature, for the experimental study of which he used a bath of boiling sulphur. He carried out analyses of the gases evolved by the Czechoslovak petroleum springs at Gbely and succeeded in removing carbon monoxide and unsaturated hydrocarbons from the gas, which is used locally for lighting and heating. Even his physicochemical researches had some bearing upon industrial technology. Thus, almost his last work was a study of the binary systems of phenol with hydrocarbons. $\mathrm{He}$ found, among other things, that phenol is a suitable reagent for the separation of hydrocarbon mixtures, being preferable to such means as nitration or bromination.

$\mathrm{He}$ was a member of many continental scientific societies and was prominent in the activities of the Masaryk Academy of Work.

G. D.

\section{Mr. A. W. Shorter}

WE regret to record the death of $\mathrm{Mr}$. A. W. Shorter, assistant keeper in the Department of Egyptian and Assyrian Antiquities of the British Museum (Bloomsbury), which took place on May 31 at the age of thirty-two years.

Alan Wynn Shorter was the son of Mr. Wilfrid Wynn Shorter, and was educated at St. Paul's School and Queen's College, Oxford, where he graduated in 1928. Before taking his degree he had for some time devoted himself to the study of Egyptology, and more especially to the study of the religious beliefs and rituals of the ancient Egyptians, as set forth in "The Book of the Dead". On leaving Oxford in 1928-9 he spent a year working on the excavations of the Egypt Exploration Society at Tell el-Amarna; and on his return to England he secured an appointment on the staff of the British Museum. Here in the Department of Egyptian Antiquities he was able to continue his study of the material culture, arts and religion of the ancient Egyptian people. He was the author of a number of popular books on these subjects, and also contributed to the publications of learned societies, specializing in the study of Egyptian papyri. His principal contribution to Egyptology is a "Catalogue of Egyptian Religious Papyri in the British Museum".

Wr regret to announce the following deaths :

Prof. R. M. Bird, professor of organic chemistry in the University of Virginia, on June 4, aged seventyone years.

Dr. B. T. Galloway, formerly pathologist in the U.S. Bureau of Plant Industry, on June 13, aged seventy-four years.

Sir Colin Mackenzie, formerly director of the Australian Institute of Anatomy, aged sixty-one years.

Mr. H. N. Thompson, C.M.G., lately director of forests, Nigeria, on July 9. 